\title{
Relationship between carcass weight, adipose tissue androstenone level and expression of the hepatic $3 \beta$ - hydroxysteroid dehydrogenase in entire commercial pigs
}

\author{
S. I. Nicolau-Solano, F. M. Whittington, J. D. Wood and O. Doran ${ }^{\dagger}$ \\ Division of Farm Animal Science, Department of Clinical Veterinary Science, University of Bristol, Langford, Bristol BS40 5DU, UK
}

(Received 17 October 2006; Accepted 4 April 2007)

Boar taint is a major meat-quality defect in pigs and is due to excessive accumulation of skatole and androstenone in adipose tissue. The present work investigated the relationship between carcass weight, levels of skatole and androstenone in adipose

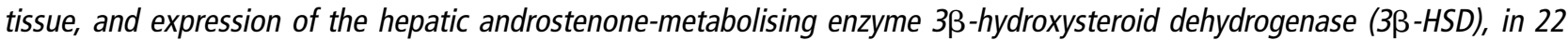
entire male and 22 entire female crossbred pigs (Large White $(40 \%) \times$ Landrace $(40 \%) \times$ Duroc $(20 \%))$. Animals of each gender were divided into two subgroups (11 pigs in each subgroup): (i) conventional weight (carcass weight 59 to $77 \mathrm{~kg}$ ) and (ii) heavy weight (carcass weight 84 to $95 \mathrm{~kg}$ ). No relationship between carcass weight and adipose tissue skatole level was found for entire male pigs $\left(\mathrm{r}^{2}=0.013, \mathrm{P}>0.05\right)$. There was a significant negative relationship between carcass weight and expression of the hepatic $3 \beta-H S D$ protein $\left(\mathrm{r}^{2}=0.502, \mathrm{P}<0.001\right)$ and a significant negative relationship between $3 \beta-H S D$ protein expression and androstenone level in adipose tissue $\left(\mathrm{r}^{2}=0.24, \mathrm{P}<0.05\right)$ in entire males. No relationship was found between

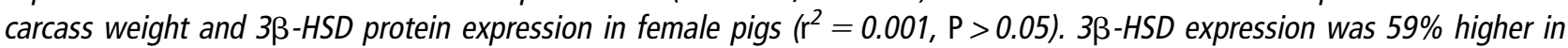
conventional-weight male pigs when compared with heavy-weight animals $(\mathrm{P}<0.05)$ and $36 \%$ higher in heavy-weight females when compared with heavy-weight males $(\mathrm{P}<0.05)$. It is concluded that an increase in slaughter weight of entire commercial crossbred Large White pigs is accompanied by inhibition of expression of the hepatic $3 \beta-H S D$ protein, which might result in a reduced rate of hepatic androstenone clearance with its subsequent accumulation in adipose tissue. It is suggested that regulation of pig hepatic $3 \beta-H S D$ expression is under the control of sex hormones.

Keywords: androstenone, boar taint, $3 \beta$-hydroxysteroid dehydrogenase, pigs

\section{Introduction}

Raising entire male pigs has a number of production, environmental and animal welfare benefits, when compared with the production of castrated animals. Entire male pigs have a better feed conversion rate, higher growth rate and lean percentage, which reduce production costs (Fowler et al., 1981; Andersson et al., 1997). In addition, entire male pigs excrete less nitrogen when compared with castrates, as they have a better efficiency for nitrogen retention and therefore such a production system is more environmentally friendly (Walstra, 1974). Furthermore, meat from entire male pigs has a lower fat content and higher level of unsaturated fatty acids (Wood and Enser, 1982; Barton-Gade, 1987), which are of direct benefit for human health.

\footnotetext{
${ }^{\dagger}$ E-mail: o.doran@bristol.ac.uk
}

Therefore, production of entire male pigs would be beneficial from an economic point of view and would also be environmentally friendly, which enhances the 'ethical quality' of pork.

However, there are a number of drawbacks, such as higher frequency of social stress displayed as fighting and aggressive behaviour, associated with the production of entire male pigs when compared with entire pigs. Aggressive behaviour can lead to carcass downgrading because of skin lesions (Warriss and Brown, 1985). The softer fat of entire males may also cause problems during processing and may also be more prone to rancidity problems (Bonneau and Squires, 2001).

A critical point in the production of entire male pigs is slaughter weight. On one hand, production of heavy carcasses is desirable, since it reduces the total animal production cost and hence improves pork market competitiveness. On the other hand, an increase in slaughter weight 
can result in an increased risk of boar taint. Therefore, one of the challenges for the pig industry is to produce heavyweight entire male pigs with a reduced incidence of boar taint.

Boar taint is one of the major meat-quality defects in pigs, which is perceived as an unpleasant odour and flavour in pork and pork products during cooking (Gower, 1972; Lundstrom and Bonneau, 1996). Boar taint may lead to a poor eating experience with the subsequent negative economic repercussion for the meat industry. Boar taint occurs at puberty in some entire male pigs due to the excessive accumulation of mainly two compounds, androstenone and skatole, in adipose tissue (Lundstrom and Bonneau, 1996). However, results in the literature regarding the relationship between carcass weight and skatole and androstenone deposition are inconsistent. Thus, positive correlations $(P<0.05)$ between carcass weight and skatole and/or androstenone levels have been reported by Mortensen et al. (1986), Walstra et al. (1999) and Sinclair et al. (2001). The other authors did not find a significant relationship $(P>0.05)$ between skatole and androstenone levels and carcass weight (Hennessy et al., 1995).

A European Union-wide study on boar taint (Matthews et al., 2000) defined skatole as a major contributor to the perception of boar taint in fresh meat and recommendations were given to optimise production factors to reduce skatole level as a short-term solution to boar taint (Bonneau et al., 2000). However, our previous work has suggested that accumulation of androstenone might be a primary event in boar taint development, since high levels of androstenone can inhibit the expression of the hepatic skatole-metabolising enzyme CYP2E1 and thus reduce the rate of hepatic skatole clearance (Doran et al., 2002a). The reason for the high androstenone accumulation in some pigs is not clear. Excessive androstenone levels can be attributed, at least partially, to defective expression and activity of the hepatic androstenone-metabolising enzyme $3 \beta$-hydroxysteroid dehydrogenase (3 $\beta$-HSD) (Doran et al., 2004; Nicolau-Solano et al., 2006). The mechanism regulating $3 \beta$-HSD expression in pig liver remains unknown. Since the incidence of boar taint increases in puberty and coincides with changes in hormonal status (Babol et al., 2004; Zamaratskaia et al., 2004), sex hormones might be one of the factors regulating the expression of pig hepatic $3 \beta$-HSD.

This study was designed with two aims: (i) to investigate the relationship between carcass weight, the level of adipose tissue androstenone and skatole and the expression of hepatic $3 \beta$-HSD in entire commercial Large White crossbred pigs and (ii) to establish whether the expression of hepatic $3 \beta$-HSD depends on the hormonal status of the animals (as determined by gender and slaughter weight).

\section{Material and methods}

\section{Animals}

In all, 44 intact commercial crossbred pigs (Large White $(40 \%) \times$ Landrace $(40 \%) \times$ Duroc $(20 \%))$ from different litters were used in this study. All the animals were reared in the same farm and under the same commercial husbandry practices. Individuals were allocated to different experimental groups (11 animals in each group) depending on gender and carcass weight immediately after slaughter. The groups were defined as: (1) conventional-weight males, (2) heavy-weight males, (3) conventional-weight females and (4) heavy-weight females. The average carcass weight with the standard errors for means for experimental groups $1,2,3$ and 4 were: $70 \pm 1.8,91 \pm 1.0,73 \pm 1.4$ and $98 \pm 4.5 \mathrm{~kg}$, respectively. Carcasses over $80 \mathrm{~kg}$ were considered as heavy-weight pigs. The UK market average carcass weight is $74 \mathrm{~kg}$ as defined by the Scientific Panel for Animal Health and Welfare (2004).

Animals were reared on a commercial standard pelleted $\operatorname{diet}(\mathrm{ABN}$, Peterborough, UK), which consisted of growing and finishing diets. The growing diet was fed ad libitum to pigs up to 12 weeks of age. This diet contained $5 \%$ vegetable oil, $18.5 \%$ crude protein, $1.20 \%$ lysine and 3.3\% crude fibre. After 12 weeks, the pigs were transferred to the finishing diet, which was fed until slaughter at 22 to 26 weeks of age. The finishing diet contained 3.5\% vegetable oil, $16.5 \%$ crude protein, $1.25 \%$ lysine and $3.8 \%$ crude fibre.

Pigs were slaughtered in the EU-approved abattoir of the Department of Clinical Veterinary Science, University of Bristol, Bristol, UK, in compliance with regulations for humane care and slaughter.

\section{Sample collection}

Samples of liver and subcutaneous fat were collected within 5 to $10 \mathrm{~min}$ after exsanguination. For enzyme expression measurement, liver samples were snap-frozen in liquid nitrogen and stored at $-80^{\circ} \mathrm{C}$ until assayed. Samples of subcutaneous fat for skatole and androstenone analyses were obtained from the region of the last cervical vertebra and kept frozen at $-20^{\circ} \mathrm{C}$ until analysed.

\section{Isolation of microsomes}

$3 \beta$-HSD is an endoplasmic reticulum-associated enzyme. Therefore, analyses of $3 \beta$-HSD protein expression were performed on isolated pig liver microsomes. The microsomes were isolated by differential centrifugation, as described previously (Doran et al., 2002b). The resulting pellet was re-suspended at a protein concentration of about $20 \mathrm{mg} / \mathrm{ml}$ in a medium containing $50 \mathrm{mmol} / \mathrm{l}$ Tris $-\mathrm{HCl}$, $10 \mathrm{mmol} / / \mathrm{KH}_{2} \mathrm{PO}_{4}, 0.1 \mathrm{mmol} / \mathrm{l}$ EDTA, 20\% glycerol and inhibitors of proteolytic enzymes antipain + pepstatin + leupeptin $(1 \mu \mathrm{g} / \mathrm{ml})$ (Sigma, Dorset, UK).

Protein levels in isolated microsomes were determined by the Bradford method (Bradford, 1976) using bovine serum albumin (fraction V) as a standard.

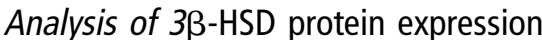

Expression of $3 \beta$-HSD protein in isolated pig liver microsomes was determined by Western blot. The optimum 
amount of protein required for the analysis has been determined in our previous work and was $6 \mu \mathrm{g}$ per well (Nicolau-Solano et al., 2006). The microsomal proteins were separated by SDS-PAGE, electroblotted onto a nitrocellulose membrane, pore size $0.45 \mu \mathrm{m}$ (Bio-Rad, Hertfordshire, UK) at a constant voltage of $100 \mathrm{~V}$ for $1 \mathrm{~h}$ and probed with rabbit anti-porcine $3 \beta$-HSD antibody for $1.5 \mathrm{~h}$. The antibody was produced against a synthetic peptide corresponding to amino acids 357 to 370 of the porcine $3 \beta$-HSD protein (GenBank accession no. NP 001004049). After probing with the primary antibody, the nitrocellulose membrane was re-probed with a commercial secondary antibody (horseradish peroxidase linked donkey anti-rabbit Ig (Amersham, Buckinghamshire, UK) for $1 \mathrm{~h}$. The complex $3 \beta$-HSDprimary antibody-secondary antibody was visualised using an enhanced chemiluminescence detection system (Amersham). The films were scanned and the intensity of the corresponding bands was quantified using the ImageQuant programme (Molecular Dynamics, Buckinghamshire, England).

\section{Analysis of androstenone in adipose tissue}

Androstenone level in adipose tissue was measured by high-resolution gas chromatography (HRGC) using a modification of the method of De Brabander and Verbeke (1986). In this procedure, $0.4 \mathrm{~g}$ of fat was saponified for $1 \mathrm{~h}$ at $60^{\circ} \mathrm{C}$ in toluene and $\mathrm{KOH}$ in methanol with $5 \alpha$-androstane-3, 17dione (Sigma) as an internal standard. After cooling, aqueous methanol was added and the samples were extracted four times with petroleum-ether (boiling point $40^{\circ} \mathrm{C}$ to $\left.60^{\circ} \mathrm{C}\right) /$ diethyl ether $(1: 1 \mathrm{vol} / \mathrm{vol})$. The pooled upper layers were reduced in volume under nitrogen before derivatisation using Tri-Sil reagent (Pierce, Cheshire, UK). The samples as tri-methyl silyl-derivatives were analysed using a Fisons 8000 series gas chromatograph (Fisons Instruments, Crawley, Sussex, England) in hot splitless/split mode (20:1), equipped with a Sil8 capillary column $(25 \mathrm{~m} \times 0.25 \mathrm{~mm}$, internal diameter) (Chrompak Ltd, Middelburg, The Netherlands), with helium as the carrier gas and using a flame ionisation detector. All analyses were performed in duplicate and the variation between duplicates was less than $10 \%$.

\section{Analysis of skatole in adipose tissue}

Adipose tissue skatole level was analysed using the simultaneous distillation/extraction procedure, with 5methylindole as an internal standard, as described by Whittington et al. (2004). Analysis was carried out using a Fisons 8000 Series HRGC, equipped with a CP57Wax capillary column $(50 \mathrm{~m} \times 0.32 \mathrm{~mm}$ internal diameter) using helium as the carrier gas, and a nitrogen-phosphorus-specific flame-ionisation detector. The linearity of the response was verified using a calibration cocktail containing known amounts of indole, skatole and 5-methylindole. All analyses were performed in duplicate and the variation between duplicates was less than $10 \%$.

\section{Statistics}

Statistical analysis of hepatic $3 \beta$-HSD was by the general linear model (Minitab, Release 14) with gender and weight as factors and including the interaction term. Paired comparisons between mean values for the significant interaction were assessed post hoc using the Tukey test at the 0.05 level. The relationships between variables (carcass weight, levels of androstenone and skatole in adipose tissue, and hepatic $3 \beta$-HSD) were investigated using simple linear regression analysis.

\section{Results}

Relationship between carcass weight and levels of skatole and androstenone in adipose tissue of entire male pigs

The relationship between carcass weight and the levels of skatole and androstenone in adipose tissue was investigated in conventional- and heavy-weight males (experimental groups 1 and 2). Figure 1 shows that an increase in carcass weight from 59 to $95 \mathrm{~kg}$ was not accompanied by changes in adipose tissue skatole level. The relationship between these two parameters was not significant $\left(r^{2}=0.013, P>0.05\right)$. The average value of adipose tissue skatole for these animals was $0.076 \pm 0.018 \mu \mathrm{g} / \mathrm{g}$ of fat. Two out of 22 entire males (9\%) had a skatole level over $0.2 \mu \mathrm{g} / \mathrm{g}$ of adipose tissue, which is the commonly used threshold value associated with boar taint (Bonneau et al., 1992). The percentage of male pigs with low (up to $0.01 \mu \mathrm{g} / \mathrm{g}$ ), medium (0.01 to $0.2 \mu \mathrm{g} / \mathrm{g}$ ) and high (more than $0.2 \mu \mathrm{g} / \mathrm{g}$ ) skatole in adipose tissue within each weight group was $80 \%, 10 \%$ and $10 \%$, respectively, for pigs under $80 \mathrm{~kg}$ carcass weight; and $90 \%, 0 \%$ and $10 \%$, respectively, for pigs over $80 \mathrm{~kg}$ carcass weight.

Regarding the carcass weight and adipose tissue androstenone (Figure 2), although the relationship was significant $(P<0.05)$, the $r^{2}$ value was low $(0.22)$. There was a large amount of scatter and the nature of the

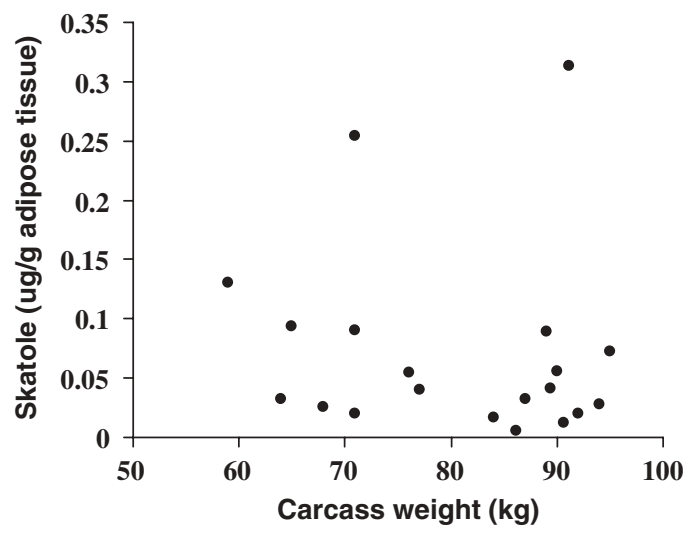

Figure 1 Relationship between carcass weight and skatole level in subcutaneous adipose tissue of entire male pigs. Each point represents an average of duplicate measurements for an individual pig. The duplicates varied by less than $10 \%$. 


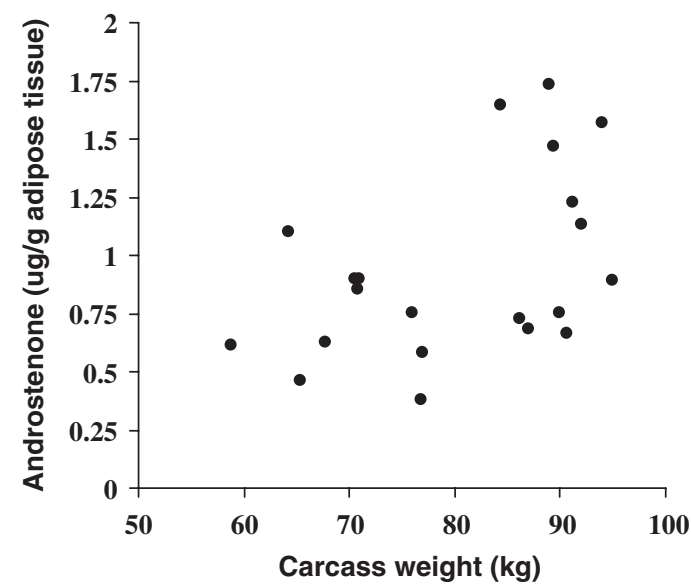

Figure 2 Relationship between carcass weight and androstenone level in subcutaneous adipose tissue of entire male pigs. Each point represents an average of duplicate measurements for an individual pig. The duplicates varied by less than $10 \%$.

relationship between these two parameters is unclear. The average value for androstenone level was $0.919 \pm 0.084 \mu \mathrm{g} / \mathrm{g}$ of adipose tissue. In the population studied, $59 \%$ of the pigs had androstenone levels between 0.5 and $1.0 \mu \mathrm{g} / \mathrm{g}$ of fat, and $32 \%$ of the animals showed androstenone levels above $1.0 \mu \mathrm{g} / \mathrm{g}$ of fat, which is the commonly used threshold androstenone value for boar taint (Desmoulin et al., 1982). The percentage of male pigs with low $(0$ to $0.5 \mu \mathrm{g} / \mathrm{g})$, medium ( 0.5 to $1.0 \mu \mathrm{g} / \mathrm{g}$ ) and high (more than $1.0 \mu \mathrm{g} / \mathrm{g}$ ) androstenone in adipose tissue within each weight group was: $18 \%, 73 \%$ and $9 \%$, respectively, for pigs under $80 \mathrm{~kg}$ carcass weight and $0 \%, 45 \%$ and $55 \%$, respectively, for pigs over $80 \mathrm{~kg}$ carcass weight.

\section{Gender and weight-related changes in expression of the hepatic $3 \beta-H S D$ protein}

Figure 3 shows that there was a significant negative relationship between adipose tissue androstenone and expression of the hepatic androstenone-metabolising enzyme $3 \beta$-HSD $\left(r^{2}=0.24, P<0.05\right)$.

To investigate the effect of the hormonal status on the expression of hepatic $3 \beta$-HSD, animals of different gender and weight were compared. A significant gender $X$ weight interaction $(F(1.40)=17.57, P<0.001)$ was found. Post hoc comparisons are shown in Figure 4 and indicate no significant differences in the levels of $3 \beta$-HSD protein expression between females of both weights and conventional-weight males. However, there was a significant difference between these three groups and the heavy-weight males. The expression of $3 \beta$-HSD was more than $40 \%$ lower for the heavy-weight males compared with the conventional-weight males. In contrast, heavy-weight females had more than $35 \%$ higher $3 \beta$-HSD protein expression when compared with heavy-weight males.

The relationship between hepatic $3 \beta$-HSD protein expression and carcass weight for male and female pigs is presented in Figure $5 a$ and $b$, respectively. There was $a$

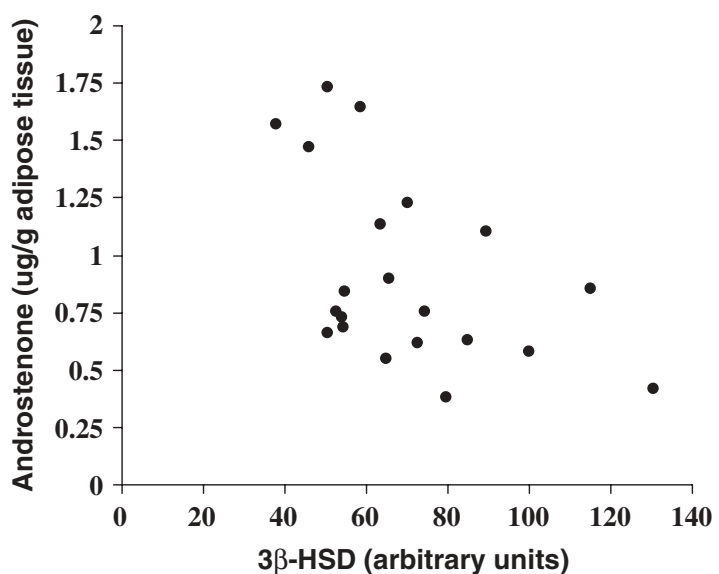

Figure 3 Relationship between $3 \beta$-hydroxysteroid dehydrogenase ( $3 \beta$ HSD) protein expression in isolated pig liver microsomes and the level of androstenone in adipose tissue in entire male pigs. Each point represents an average of duplicate measurements for an individual pig. The duplicates varied by less than $10 \%$.

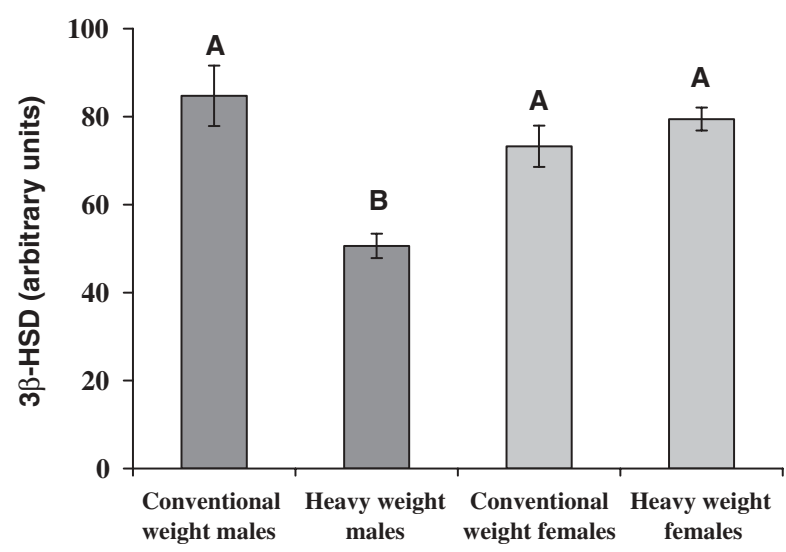

Figure 4 Expression of $3 \beta$-hydroxysteroid dehydrogenase (3 $\beta$-HSD) protein in isolate microsomes from liver of conventional and heavy-weight male and female pigs. Each bar represents a mean value for 11 animals. Measurements for each animal had been done in duplicates. The error bars represent standard error for means. Bars with different superscripts differ significantly. One sample from a particular pig (the reference sample) was present on every blot and the $3 \beta$-HSD protein content of this sample was taken as 100 arbitrary units throughout. The amount of $3 \beta$ HSD in other samples on the blot was expressed as a percentage of the reference sample.

significant negative correlation between these two parameters for males $\left(r^{2}=0.502, P<0.001\right.$; Figure $\left.5 a\right)$, while no significant relationship was found for females $\left(r^{2}=0.001, P>0.05\right.$; Figure $\left.5 b\right)$.

\section{Discussion}

Until recently it has been generally accepted that the main reason for excessive accumulation of androstenone in adipose tissue is its overproduction in the testis (Forland et al., 1980; Schinckel et al., 1984; Oonk et al., 1995). However, during the last few years it has been shown that adipose 

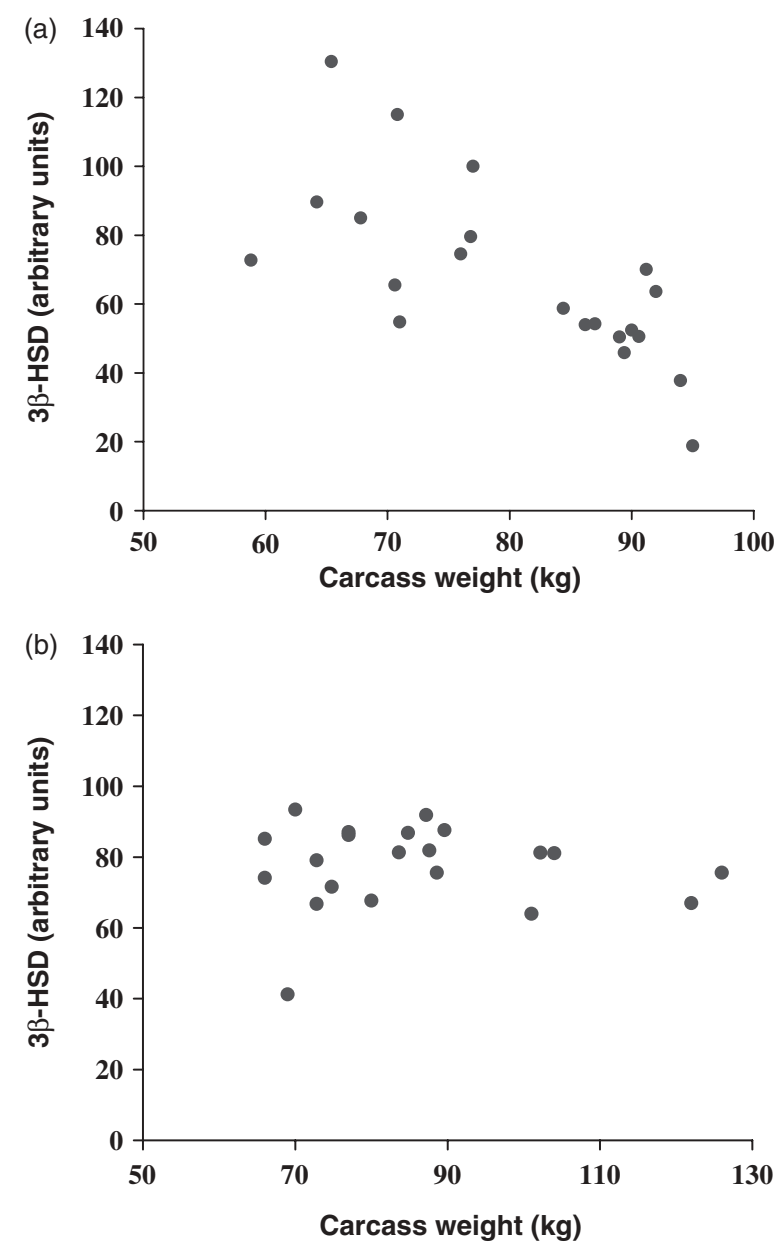

Figure 5 (a) Relationship between $3 \beta$-hydroxysteroid dehydrogenase $(3 \beta-H S D)$ protein expression in microsomes isolated from liver of entire male pigs and carcass weight. Each point represents an average of duplicate measurements for an individual pig. The duplicates varied by less than $10 \%$. (b) Relationship between $3 \beta$-hydroxysteroid dehydrogenase $(3 \beta-\mathrm{HSD})$ protein expression in microsomes isolated from liver of entire female pigs and carcass weight. Each point represents an average of duplicate measurements for an individual pig. The duplicates varied by less than $10 \%$.

tissue androstenone accumulation also depends on the rate of its clearance in the liver (Babol et al., 1999; Doran et al., 2004; Sinclair et al., 2005). 3 $\beta$-HSD is the key enzyme involved in androstenone metabolism in pig liver (Doran et al., 2002b; Sinclair et al., 2005). Animals with a high androstenone level have low $3 \beta$-HSD activity, mRNA and protein levels (Doran et al., 2004; Nicolau-Solano et al., 2006).

In the present study, the expression of hepatic $3 \beta$-HSD was negatively related to carcass weight of entire male pigs and to androstenone level in subcutaneous adipose tissue. The $r^{2}$ value (0.24) for the relationship between $3 \beta$-HSD expression and androstenone level in the present study was lower when compared with the $r^{2}$ value $(0.64)$ in our previous study on Meishan and Large White crossbreeds. This could be due to using animals of different breeds and weights in these two studies. It is possible that the mechanisms regulating $3 \beta$-HSD expression and androstenone deposition are breed specific. Our earlier work showed that there is a breed-specific regulation of deposition of the other boar taint compound, skatole (Doran et al., 2002b).

The low expression of hepatic $3 \beta$-HSD in heavy-weight pigs observed in this study suggests that the rate of androstenone degradation in the liver of these pigs was lower when compared with the conventional-weight animals. A reduced rate of hepatic androstenone catabolism via $3 \beta-H S D$ could be one of the possible explanations for an increase in the level of androstenone in adipose tissue with increasing carcass weight, as reported by Bonneau (1987), Walstra et al. (1999) and Sinclair et al. (2001). However, there are also a number of publications that did not find any correlation between backfat androstenone and carcass weight (LeDenmat et al., 1993; Neupert et al., 1995). The present study has also investigated the relationship between androstenone and carcass weight and has shown that although the relationship between these two parameters was significant $(P<0.05)$, the $r^{2}$ value of 0.22 indicates that only $22 \%$ of the variation in androstenone level can be explained by association with carcass weight.

Average levels of both androstenone and skatole in adipose tissue from entire males $(0.919$ and $0.076 \mu \mathrm{g} / \mathrm{g}$, respectively) were below the commonly used respective thresholds for tainted meat ( 1.0 and $0.2 \mu \mathrm{g} / \mathrm{g}$, respectively) (Desmoulin et al., 1982; Mortensen et al., 1986; Bonneau et al., 1992). In the present study, around $32 \%$ of the entire male pigs showed androstenone levels above the commonly used threshold for boar taint perception. These results are in agreement with the data of the international study where over 4000 fat samples from entire males from six European countries were analysed (Walstra et al., 1999). The percentage of pigs with medium androstenone level $(0.5$ to $1.0 \mu \mathrm{g} / \mathrm{g})$ was higher in the present study compared with data for the UK pigs in the European study $(59 \% \mathrm{v}$. $30.9 \%$ ). This might be due to differences in the average carcass weight between pigs used in these two studies $(80$ and $65 \mathrm{~kg}$, respectively). The results for skatole in the present work show that only $9 \%$ of entire males had a level of skatole above the threshold for boar taint. These results are not consistent with the finding of the international study, which reported that around 15\% of entire males have skatole level above the threshold (Walstra et al., 1999). This discrepancy between the results may be due a number of factors such as the use of different techniques for skatole measurement. In the present work, skatole level was detected by HRGC, whereas in the international study a colorimetric assay was used. The colorimetric assay detects not only skatole but the sum of skatole and skatole-related compounds, such as indole (Mortensen et al., 1986). The other explanation for variation between our results and the data of the international study could be that different genotypes and production systems were used.

The fact that in our study the percentage of pigs with androstenone level exceeding the commonly used threshold for boar taint was higher than the percentage of animals 
with elevated skatole level (35\% v. 9\%) might indicate that androstenone accumulation might be a primary event in the development of boar taint. This is consistent with our previous finding in cell culture experiments that androstenone inhibits the expression of the skatole-metabolising enzyme CYP2E1 in pig liver, which leads to a reduction of the rate of hepatic skatole clearance with subsequent skatole accumulation in adipose tissue (Doran et al., 2002a). Gillberg et al. (2006) demonstrated that sex steroids can also affect the expression of another hepatic skatole-metabolising enzyme, CYP2A. In their study, the castration of mature minipig boars resulted in a significant increase in the hepatic CYP2A mRNA, protein and enzyme activity. The mechanism of androstenone action on CYP2E1 expression has been investigated in our previous study and it established that the inhibitory effect of androstenone is mediated via inhibition of binding of the transcription factor COUP-TF1 to the pig CYP2E1 promoter (Tambyrajah et al., 2004).

Not only CYP2E1 expression but also CYP2E1 activity can be modulated by androstenone. Zamaratskaia et al. (2007) demonstrated a decrease in CYP2E1 catalytic activity in the presence of micromolar concentration of androstenone in microsomes isolated from liver of male pigs. The CYP2E1 activity in this system was also inhibited by another testicular steroid, $17 \beta$-oestradiol, but not by testosterone. It is presently unknown whether the effect of $17 \beta$-oestradiol on CYP2E1 activity is mediated via modulation of CYP2E1 expression or whether CYP2E1 expression can be regulated by sex steroids other than androstenone.

As it has been mentioned above, an excessive accumulation of androstenone in pig adipose tissue is related to a defective expression of the hepatic $3 \beta$-HSD and, as a consequence, to a low rate of hepatic androstenone metabolism. The mechanism regulating the expression of pig hepatic $3 \beta$-HSD is not clear. Studies on $3 \beta$-HSD in various tissues in rats and mice established that $3 \beta$-HSD expression in these species is under the control of sex steroids (Naville et al., 1991; Soma et al., 2005). The present study has shown that the expression of hepatic $3 \beta$-HSD protein significantly differed between animals of different genders (conventional-weight males and females). Moreover, in the present study we have also observed a $59 \%$ decrease in $3 \beta$-HSD protein expression in heavyweight males (92 kg mean carcass weight) when compared with conventional-weight males $(70 \mathrm{~kg}$ mean carcass weight). The onset of puberty is thought to be linked to the weight and the age of the pigs (Einarsson et al., 1979; Schinckel et al., 1984; Prunier et al., 1987). Generally, the pubertal development of boars occurs around the age of 5 to 6 months (Claus et al., 1994). The carcass weight of Large White male pigs at this age is around $70 \mathrm{~kg}$ (Dede, 1983), which corresponds to the carcass weight of animals in the conventional group of the present study. Since the animals in the present work were from the same crossbreed, were reared under the same husbandry system and were fed with the same diet, the weight of the animals was taken as a simplified indicator of sexual maturity and hence as the hormonal status of the pigs. Therefore, the weightdependent variation in $3 \beta$-HSD protein level might also be considered as an indication of hormonal regulation of $3 \beta$ HSD expression. Further experiments are currently being carried out in our group to establish the effect of individual sex steroids on $3 \beta$-HSD expression using cell culture as a model system.

In conclusion, the present study demonstrates that an increase in the slaughter weight of entire commercial crossbred Large White male pigs is accompanied by an inhibition of hepatic $3 \beta$-HSD protein expression. The expression of pig hepatic $3 \beta$-HSD protein depends on the gender and weight of animals, which suggests that $3 \beta$-HSD expression might be under the control of sex hormones. Low expression of $3 \beta$-HSD in heavy-weight pigs was accompanied by an increased level of androstenone in subcutaneous adipose tissue, which might be due to a reduced rate of androstenone clearance in liver of these animals.

\section{Acknowledgments}

This research was funded by Biotechnology and Biological Sciences Research Council (BBSRC) and Department for Environment, Food and Rural Affairs (DEFRA). S. I. NicolauSolano is a recipient of a BBSRC/Genesis Faraday CASE studentship with the Meat and Livestock Commission as an Industrial partner. We thank Mrs Sue Hughes for assistance with statistical analyses.

\section{References}

Andersson K, Schaub A, Andersson K, Lundström K, Thomke S and Hansson I 1997. The effect of feeding system, lysine level and gilt contact on performance, skatole levels and economy of entire male pigs. Livestock Production Science 51, 131-140.

Babol J, Squires EJ and Lundström K 1999. Relationship between metabolism of androstenone and skatole in intact male pigs. Journal of Animal Science 77, 84-92.

Babol J, Zamaratskaia G, Juneja K and Lundström K 2004. The effect of age on distribution of skatole and indole levels in entire male pigs in four breeds: Yorkshire, Landrace, Hampshire and Duroc. Meat Science 67, 351-358.

Barton-Gade P 1987. Meat and fat quality in boars, castrates and gilts. Livestock Production Science 16, 187-196.

Bonneau M 1987. Effects of age and live weight on fat $5 \alpha$-androstenone levels in young boars fed two planes of nutrition. Reproduction, Nutrition, Development 27, 413-422.

Bonneau M and Squires EJ 2001. Use of entire males for pig production. Proceedings of the First International Virtual Conference on Pork Quality: Welfare, Transport, Slaughter and Consumer. Concordia, Brazil, 69, 178-202.

Bonneau M, LeDenmat M, Vaudelet JC, Jeloso Nunes JR, Mortensen AB and Mortensen HP 1992. Contributions of fat androstenone and skatole to boar taint: I. Sensory attributes of fat and pork meat. Livestock Production Science 32, 63-80.

Bonneau M, Walstra P, Claudi-Magnussen C, Kempster AJ, Tornberg E, Fischer K, Diestre A, Siret F, Chevillon P, Claus R, Dijksterhuis GB, Punter P, Matthews KR, Agerhem H, Beague MP, Oliver MA, Gispert M, Weiler von Seth G, Leask H, Font i Furnol M, Homer DB and Cook GL 2000. An international study on the importance of androstenone and skatole for boar taint: IV. Simulation studies on consumer dissatisfaction with entire male pork and the effect of sorting out 
carcasses on the slaughter line, main conclusions and recommendations. Meat Science 54, 285-295.

Bradford MM 1976. A rapid and sensitive method for the quantification of microgram quantities of protein utilizing the principle of protein-dye binding. Analytical Biochemistry 72, 248-254.

Claus R, Weiler U and Herzog A 1994. Physiological aspects of androstenone and skatole formation in the boar. A review with experimental data. Meat Science 38, 289-305.

De Brabander HF and Verbeke R 1986. Quantitative determination of androstenone in pig adipose tissue. Journal of Chromatography 363, 293-302. Dede TI 1983. Thermal adaptability of Large White pigs in the tropical environment. International Journal of Biometeorology 27, 249-258.

Desmoulin B, Bonneau M, Frouin A and Bidard JP 1982. Consumer testing of pork and processed meat from boar: the influence of fat androstenone level. Livestock Production Science 9, 707-715.

Doran E, Whittington FM, Wood JD and McGivan JD 2002a. Cytochrome 450 IIE1 (CYP2E1) is induced by skatole and this induction is blocked by androstenone in isolated pig hepatocytes. Chemico-Biological Interactions 140, 81-92.

Doran E, Whittington FW, Wood JD and McGivan JD 2002b. The relationship between adipose tissue skatole levels, rates of hepatic microsomal skatole metabolism and hepatic cytochrome P450IIE1 expression in two breeds of pig. Animal Science 74, 461-468.

Doran E, Whittington FM, Wood JD and McGivan JD 2004. Characterisation of androstenone metabolism in pig liver microsomes. Chemico-Biological Interactions 147, 141-149.

Einarsson S, Holtman M, Larsson K, Settergren I and Bane A 1979. The effect of two different feed levels on the development of the reproductive organs in boars. Acta Veterinaria Scandinavica 20, 1-9.

Forland DM, Lunstrom K and Andresen 0 1980. Relationship between androstenone content in fat, intensity of boar taint and size of accessory sex glands in boars. Nordisk Veterinaermedicin 32, 201-206.

Fowler VR, McWilliam T and Aitken R 1981. Voluntary feed intake of boars, castrates and gilts given diets of different nutrient density. Animal Production 32, 357(abstr.).

Gillberg M, Skaanild MT and Friis C 2006. Regulation of gender-dependent CYP2A expression in pigs: involvement of androgens and CAR. Basic and Clinical Pharmacology and Toxicology 98, 480-487.

Gower DB 1972. 16-unsaturated C19 steroids. A review of their chemistry, biochemistry and possible physiological role. Journal of Steroid Biochemistry 3 45-103.

Hennessy D, Salvatore L and Sali L 1995. Incidence and nature of boar taint in Australian pigs. Proceedings of the Meeting of the EAAP Working Group Production and Utilization of Meat from Entire Male Pigs. Session III, Milton Keynes, UK, p 5.

LeDenmat M, Hervo N, Vaudelet JC and Bonneau M 1993. The effect of slaughter weight on fat androstenone and skatole levels and on the assessment of boar taint in entire male pigsin:Measurement and prevention of boar taint in entire male pigs (ed. M Bonneau), pp. 167-171. Les Colloques 60, INRA, Paris.

Lundstrom K and Bonneau M 1996. Off-flavour in meat with particular emphasis on boar taintIn:Meat quality and meat packaging (ed. S Tylor, A Raimundo, M Severini, FJM Smulders), pp. 137-154. ECCEAMST, Utrecht.

Matthews KR, Homer DB, Punter $P$, Béague MP, Gispert $M$, Kempster $A J$, Agerhem $\mathrm{H}$, Claudi-Magnussen $\mathrm{C}$, Fischer $\mathrm{K}$, Siret $\mathrm{F}$, Leask $\mathrm{H}$, Font i Furnols $\mathrm{M}$ and Bonneau M 2000. An international study on the importance of androstenone and skatole for boar taint: III. Consumer survey in seven European countries. Meat Science 54, 271-283.

Mortensen $A B$, Bejerholm $C$ and Pedersen JK 1986. Consumer test of meat from entire males, in relation to skatole in backfat. Proceedings of 32nd European Meeting of Meat Research Workers, Ghent, Belgium, p. 23.
Naville D, Keeney DS, Jenkin G, Murry BA, Head JR and Mason J 1991 Regulation of expression of male-specific rat liver microsomal 3 betahydroxysteroid dehydrogenase. Molecular Endocrinology 5, 1090-1100.

Neupert B, Claus R, Herbert E and Weiler U 1995. Influence of sex, energy supply and light on fattening traits and carcass composition and their relation to androstenone and skatole concentrations in adipose tissue of pigs. Züchtungskunde 67, 317-331.

Nicolau-Solano SI, McGivan JD, Whittington FM, Nieuwhof GJ, Wood JD and Doran 0 2006. Relationship between the expressions of hepatic but not testicular $3 \beta$-hydroxysteroid dehydrogenase with androstenone deposition in pig adipose tissue. Journal of Animal Science 84, 2809-2817.

Oonk HB, Turkstra JA, Lankhof H, Schaaper WMM, Verheijden JHM and Meloen RH 1995. Testis size after immunocastration as parameter for the absence of boar taint. Livestock Production Science 42, 63-71.

Prunier A, Bonneau M and Etienne M 1987. Effects of age and live weight on the sexual development of gilts and boars fed two planes of nutrition. Reproduction, Nutrition, Development 27, 689-700.

Schinckel AP, Johnson RK and Kittok RJ 1984. Testicular development and endocrine characteristics of boars selected for either high or low testis size. Journal of Animal Science 58, 675-685.

Scientific Panel for Animal Health and Welfare 2004. Report on request from the Commission related to welfare aspects of the castration of piglets. Welfare aspect of castration of piglets. EFSA Journal 91, 11/100.

Sinclair PA, Squires EJ and Raeside JI 2001. Early postnatal plasma concentrations of testicular steroid hormones, pubertal development, and carcass leanness as potential indicators of boar taint in market weight intact male pigs. Journal of Animal Science 79, 1868-1876.

Sinclair PA, Hancock S, Gilmore WJ and Squires EJ 2005. Metabolism of the 16 androstene steroids in primary cultured porcine hepatocytes. Journal of Steroid Biochemistry and Molecular Biology 96, 79-87.

Soma KK, Sinchak K, Lakhter A, Schilinger BA and Micevych PE 2005. Neurosteroids and female reproduction: estrogen increases $3 \beta$-HSD mRNA and activity in rat hypothalamus. Endocrinology 146, 4386-4390.

Tambyrajah WS, Doran E, Wood JD and McGivan JD 2004. The pig CYP2E1 promoter is activated by COUP-TF1 and HNF-1 and is inhibited by androstenone. Archives of Biochemistry and Biophysics 431, 252-260.

Walstra P 1974. Fattening of young boars: quantification of positive and negative aspects. Livestock Production Science 1, 187-196.

Walstra $P$, Claudi-Magnussen $C$, Chevillon $P$, von Seth $G$, Diestre A, Mathews KR, Homer DB and Bonneau M 1999. An international study on the importance of androstenone and skatole for boar taint: levels of androstenone and skatole by country and season. Livestock Production Science $62,15-28$.

Warriss PD and Brown SN 1985. The physiological-responses to fighting in pigs and the consequences for meat quality. Journal of the Science of Food and Agriculture 36, 87-92.

Whittington FM, Nute GR, Hughes SI, McGivan JD, Lean IJ, Wood JD and Doran E 2004. Relationships between skatole and androstenone accumulation, and cytochrome P4502E1 expression in Meishan and Large White pigs. Meat Science 67, 569-576.

Wood JD and Enser M 1982. Comparison of boars and castrates for bacon production. 2. Composition of muscle and subcutaneous fat, and changes in side weight during curing. Animal Production 35, 65-74.

Zamaratskaia G, Babol J, Madej A, Squires EJ and Lunstrom K 2004. Agerelated variation of plasma concentration of skatole, androstenone, testosterone, oestradiol-17 $\beta$, oestrone sulphate, dehydroepiandrosterone sulphate, triidothyronine and IGF-1 in six entire male pigs. Reproduction in Domestic Animals 39, 168-172.

Zamaratskaia G, Gilmore WJ, Lundstrom K and Squires EJ 2007. Effect of testicular steroids on catalytic activities of cytochrome P450 enzymes in porcine liver microsomes. Food and Chemical Toxicology 45, 676-681. 